\title{
ETNOMUSIKOLOGIAN HYVÄT JA HUONOT UUTISET
}

Etnomusikologia koki Suomessa takaiskun loppukesästä 2019, kun musiikin tutkimista koskeva kokonaisuus poistui virallisesti Tampereen yliopiston opetusohjelmasta. Etnomusikologiaa ryhdyttiin Suomessa opettamaan ensimmäisen kerran Helsingin yliopistossa 1970-luvun alussa, mutta Tampereen yliopisto seurasi pian perässä ja päätyi lopulta ainoana yliopistona Pohjoismaissa järjestämään tästä tutkimussuuntauksesta pääaineopetusta (ks. Rautiainen-Keskustalo 2015). Tampereen asema alan kotimaisessa tutkimuksessa on ollut enemmän kuin huomattava. Kun Meri Kytö ja Saijaleena Rantanen (2014) selvittivät Etnomusikologian vuosikirjan merkitystä Suomessa tehdylle musiikintutkimukselle, eräs havainnoista oli se, että Tampereen yliopiston tutkijat olivat suorastaan dominoineet vuosikirjan sisältöä. Tamperelaisten tekemiä artikkeleita ilmestyi kirjan sivuilla 1986-2014 yhtä paljon kuin Helsingin yliopiston, Turun yliopiston ja Åbo Akademin tutkijoiden artikkeleita yhteensä.

Enää Suomessa ei järjestetä systemaattista ja laajaa etnomusikologian opetusta. Tästä ei tietenkään pidä vetää sellaista johtopäätöstä, että etnomusikologinen tutkimus olisi Suomessa menettänyt merkitystään, saati kuollut. Ehkä tutkimus vain on palannut juurilleen piipahdettuaan hetkeksi yliopiston käytävillä, ja nyt se vaeltaa ajatuksena, teorioina, perinteenä ja mikä ettei käytänteinäkin musiikintutkimuksen yhteisöissä. Etnomusikologian aika on kenties terminologisesti tullut tienristeykseen, ellei peräti tiensä päähän, onhan varsinkin etno-sana kaik- 
kine mielleyhtymineen ja ongelmineen omalla tavallaan aikansa elänyt, mutta voidaan silti hyvällä syyllä väittää, että tutkimussuuntauksen perintö elää vahvana, erityisesti kulttuurisen musiikintutkimuksen muodossa.

Tässä vuosikirjassa etnomusikologisen perinteen kirjo näyttäytyy monissa eri asuissaan. Timo Leisiö tarkastelee tieteenhistoriallisessa katsauksessaan vertailevan musiikintutkimuksen varhaisvaiheita niin Saksassa kuin Suomessa ja kuuluttaa tutkimusperinteen tuntemisen tärkeyttä - mutta myös tutkijoiden kykyä tarvittaessa irtautua siitä. Seuraavat kolme artikkelia asettuvat etno-etuliitteen monella tapaa korvanneen kulttuurisen musiikintutkimuksen uudempaan vuohon: Oili Paaskoski, Salli Anttonen ja Ida-Meri Havukainen tarkastelevat muun muassa populaarimusiikin diskursiivisia käytänteitä ja identiteettien tuottamisia sekä laulunopetuksen materiaalisia ja kehollisia ulottuvuuksia. Artikkelit heijastavat humanistisen ja yhteiskuntatieteellisen tutkimuksen viimeisimpiä linjoja, joista esimerkiksi uusmateriaalisuuden tutkimus on saavuttanut jalansijaa myös suomalaisen musiikintutkimuksen kentällä. Helen Kõmmusin artikkeli sen sijaan palaa kohti etnomusikologian klassisia juuria: kansanmusiikkien tutkimukseen, kenttätöihin ja tutkijan havainnoivaan läsnäoloon musisoivien yhteisöjen parissa.

Kirjan päättää Vesa Kurkela, joka palaa palaa kahdenkymmenen vuoden takaiseen, 180o-luvun sointikuvaa käsittelevään vuosikirja-artikkeliinsa ja pohtii sen merkitystä niin hänen omalle ajattelulleen kuin laajemmin nykyiselle musiikintutkimukselle. Haluamme vanhan artikkelin uudelleenjulkaisulla kunnioittaa historiallisiin aiheisiin mieltyneen professori Kurkelan pitkää tutkijauraa - hän oli muun muassa toimittamassa kaikkien aikojen ensimmäistä Etnomusikologian vuosikirjaa vuonna 1986.

Tämä kirja on hatunnosto myös toiselle merkittävälle musiikintutkijalle. Vuosikirjan onnitteluperinteitä noudattaen teos on omistettu 50 vuotta täyttävälle professori Antti-Ville Kärjälle, joka on toiminut aktiivisesti Suomen etnomusikologisen seuran riveissä 1990-luvulta lähtien, viimeksi puheenjohtajana 2016-2019. 


\section{Kirjallisuus}

Kytö, Meri \& Rantanen, Saijaleena (2014) "Etnomusikologian vuosikirjan merkitys musiikintutkimuksen alalle Suomessa". Etnomusikologian vuosikirja Vol. 26, 8-25. https://doi. org/10.23985/evk.66786

Rautiainen-Keskustalo, Tarja (2015) "Kansalliset tieteet, etnomusikologia ja liikkuvan maailman problematiikka". Elore Vol. 22, 1-19. http://www.elore.fi/arkisto/2_15/rautiainenkeskustalo.pdf 